\title{
Alteration of REDD1-Mediated Mammalian Target of Rapamycin Pathway and Hypoxia-Inducible Factor-1 $\alpha$ Regulation in Human Breast Cancer
}

\author{
Ja Seung Koo Woohee Jung \\ Department of Pathology, Yonsei University Health System, Seoul, South Korea
}

\section{Key Words}

Hypoxia - REDD1 - Mammalian target of rapamycin •

Hypoxia-inducible factor- $1 \alpha \cdot$ Breast neoplasm

\begin{abstract}
Objective: The purpose of this study is to investigate REDD1(regulated in development and DNA damage response 1) mediated regulation of the mammalian target of rapamycin (mTOR) pathway in breast cancer. Methods: A tissue microarray included samples from 224 patients with breast cancer, and 30 patients with papilloma were used as a control group. An immunohistochemistry (IHC) including estrogen receptor (ER), progesterone receptor (PR), human epidermal growth factor receptor 2 (HER2), epithelial growth factor receptor, cytokeratin 5/6, glucose transporter 1 (Glut-1), hypoxia-inducible factor (HIF)- $1 \alpha$, REDD1, AMPK (5'-adenosinemonophosphate-activated protein kinase) $\alpha_{1}, 14-3-3 \sigma$, phosphatase and tensin homolog, phospho-Akt, phospho-mTOR, phospho-S6, and Ki-67 was conducted. The phenotypic classification of breast cancer was performed based on the results of the IHC for ER, PR and HER2: luminal A, luminal B, HER2 overexpression and triple-negative breast cancer (TNBC). Results: Glut-1 and HIF-1 $\alpha$ were more highly expressed in TNBC, the HER2 overexpression type and papilloma than in the luminal $A$ and $B$ phenotypes $(p=0.000)$.
\end{abstract}

REDD1 expression was higher in papilloma than in breast cancer ( $p=0.000)$, but no difference was found among the 4 breast cancer phenotypes ( $p=0.307$ ). Conclusion: In the HER2 overexpression type and TNBC, tumor cell proliferation and survival in the hypoxic tumor environment could possibly be due to disinhibition of the mTOR pathway and HIF-1 $\alpha$ stabilization by downregulation of REDD1.

Copyright $\odot 2011$ S. Karger AG, Basel

\section{Introduction}

Breast cancer is a heterogeneous disease which is diverse in behavior, outcome and response to treatment. Recent studies by gene expression profiling to classify heterogeneous breast cancer enabled the identification of 5 different subtypes of breast cancer with a distinct molecular signature and clinical implications: normal breastlike, luminal A, luminal B, human epidermal growth factor receptor 2 (HER2) overexpression and basal-like phenotypes [1-4]. Immunohistochemical studies support this breast cancer classification by molecular signature to a certain extent [5-7]. The triple-negative breast cancer (TNBC) has been used as a surrogate for the basal-like phenotype because most basal-like phenotypes do not express estrogen receptor (ER), progesterone receptor

\section{KARGER}

Fax +4161306 1234 E-Mail karger@karger.ch www.karger.com

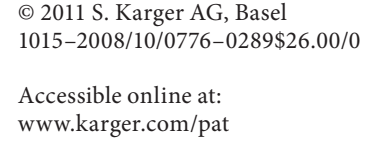

Dr. Woohee Jung, MD, PhD

Department of Pathology, Yonsei University Health System

Gangnam Severance Hospital

612 Eonjuro Gangnam-gu, Seoul 135-720 (South Korea)

Tel. +82 22019 3541, Fax +82 23463 2103, E-Mail Jungwh96@yuhs.ac 
(PR) and HER2, and it has the advantage that those 3 stains are already routinely used in the clinical workup of breast cancer $[5,8]$. Among these phenotypes, histological features of the HER2 overexpression and TNBC types are reported to be associated with high tumor grade, increased proliferation activity and areas of geographic tumor necrosis $[5,6,8-12]$. According to the histological features of geographic tumor necrosis with a high mitotic index in HER2 overexpression and TNBC types, it could be assumed that the tumor environment of these types was frequently exposed to hypoxic conditions. When normal cells were exposed to hypoxic conditions, REDD1 (regulated in development and DNA damage response 1) was induced [13], and induced REDD1 shut off $14-3-3 \sigma$, which was combined with the tuberous sclerosis (TSC)1-TSC2 complex. The REDD1-mediated 14-3-30 shuttling helped a TSC1-TSC2 complex recover its function [14-17]. A TSC1-TSC2 complex inhibits the mammalian target of rapamycin (mTOR) pathway via inhibition of Rheb (Ras homolog enriched in brain), and eventually gives rise to the inhibition of cell growth and survival. However, the REDD1-mediated regulation of the mTOR pathway in human breast cancer has not been well studied. A previous in vitro cell culture study showed that cells under hypoxic conditions demonstrated anchorage-independent growth when REDD1 was downregulated, and a study of human breast cancer tissue showed that $30 \%$ of breast cancers revealed a significant downregulation of REDD1 [15]. In addition, other hypoxia-related proteins such as hypoxia-inducible factor (HIF)- $1 \alpha$ and AMPK (5'-adenosine-monophosphateactivated protein kinase) are reported to be related to REDD1 [13, 18].

The purpose of this study is to investigate the REDD1mediated regulation of the mTOR pathway and the relation of REDD1 to other hypoxia-related proteins such as HIF- $1 \alpha$ and AMPK in HER2 overexpression and TNBC subtypes which showed geographic tumor necrosis with a high mitotic index.

\section{Materials and Methods}

\section{Patient Selection}

From the Department of Pathology of Severance Hospital we retrieved tissue samples of patients with breast invasive ductal carcinoma, which were filed between January 2000 and December 2001. This study was approved by the institutional review board of Severance Hospital. Formalin-fixed and paraffin-embedded tissue specimens from 224 cases of primary breast cancer were included. All archival hematoxylin and eosin (HE)-stained slides for each case were reviewed by 2 pathologists (J.S.K. and
W.J.). The histological grade was assessed using the Nottingham grading system [19], and the nuclear grade was evaluated according to the modified Black nuclear grade $(1=$ low grade, $2=$ intermediate grade and $3=$ high grade) [20]. Histological parameters such as histological subtype, nuclear grade and histological grade were evaluated from HE-stained slides. Clinical parameters which were evaluated for each tumor included patient age at initial diagnosis, lymph node status, local recurrence, systemic recurrence and patient's survival. Thirty cases of intraductal papilloma with florid usual ductal hyperplasia were selected as a benign control group.

\section{Tissue Microarray}

On HE-stained slides of tumors, a representative area was selected and a corresponding spot marked on the surface of the paraffin block. Using a biopsy needle, the selected area was punched out and a $3-\mathrm{mm}$ tissue core placed into a $6 \times 5$ recipient block. Tissue of invasive tumor, intraductal component, lymph node metastasis and recurred tumor, if existing, was extracted. More than 2 tissue cores were extracted to minimize extraction bias. Each tissue core was assigned a unique tissue microarray location number that was linked to a database containing other clinicopathologic data.

\section{Immunohistochemistry}

The antibodies used for immunohistochemistry (IHC) in this study are shown in table 1 . All immunostaining was performed using formalin-fixed, paraffin-embedded tissue sections. $5-\mu \mathrm{m}$ thick sections were obtained with a microtome, transferred to adhesive slides and dried at $62^{\circ} \mathrm{C}$ for $30 \mathrm{~min}$. The sections were then placed in a glass jar with $10 \mathrm{mM}$ citrate buffer ( $\mathrm{pH}$ 6.0) and irradiated in a microwave oven for $15 \mathrm{~min}$. The sections were allowed to cool in the jar at room temperature for $20 \mathrm{~min}$. The slides were then rinsed with Tris-buffered saline. A blocking reagent was added for $10 \mathrm{~min}$ after having quenched the endogenous peroxidase activity in $0.3 \%$ hydrogen peroxide for $10 \mathrm{~min}$. After incubation with primary antibodies, immunodetection was performed with biotinylated anti-mouse immunoglobulin, followed by peroxidase-labeled streptavidin using a labeled streptavidin biotin kit with 3,3'-diaminobenzidine chromogen as a substrate. The optimal primary antibody incubation time and concentration were determined via serial dilution for each immunohistochemical assay with an identically fixed and embedded tissue block. Slides were counterstained with Harris hematoxylin. The staining was interpreted by 2 pathologists (J.S.K. and W.J.) under a multiview microscope. Different results were discussed, and in case of persistent disagreement, a third pathologist was consulted.

\section{Interpretation of IHC Stainings}

All immunohistochemical markers were accessed by light microscopy. Immunostained slides were scored according to the percentage of tumor cells exhibiting nuclear (ER, PR, HIF-1 $\alpha$ and Ki-67), cytoplasmic [cytokeratin 5/6 (CK5/6), 14-3-3 $\sigma$, phosphatase and tensin homolog (PTEN), HIF-1 $\alpha$, AMPK $\alpha_{1}$, phosphoAkt, phospho-mTOR, phospho-S6 and REDD1] and membrane [HER2, epithelial growth factor receptor (EGFR) and glucose transporter 1 (Glut-1)] staining. A cutoff value of $1 \%$ or more positively stained nuclei was used to define ER and PR positivity. HER2 staining was analyzed according to the American Society of Clinical Oncology (ASCO)/College of American Pathologists 
Table 1. Clones, dilutions and sources of antibodies used

\begin{tabular}{|c|c|c|c|}
\hline Antibody & Clone & Dilution & Source \\
\hline \multicolumn{4}{|l|}{ Phenotype-related } \\
\hline ER & SP1 & $1: 100$ & Thermo Scientific, Calif., USA \\
\hline $\mathrm{PR}$ & PgR & $1: 50$ & DAKO, Denmark \\
\hline HER2 & polyclonal & $1: 1,500$ & DAKO, Denmark \\
\hline \multicolumn{4}{|l|}{ Basal type-related } \\
\hline EGFR & EGFR.25 & $1: 50$ & Novocastra, UK \\
\hline CK5/6 & D5/16B4 & $1: 100$ & DAKO, Denmark \\
\hline \multicolumn{4}{|l|}{ Hypoxia-related } \\
\hline Glut-1 & SPM498 & $1: 200$ & Abcam, UK \\
\hline HIF- $1 \alpha$ & EP1215Y & $1: 100$ & Biocare, Calif., USA \\
\hline REDD1 & polyclonal & $1: 50$ & Abcam, UK \\
\hline \multicolumn{4}{|l|}{ mTOR-pathway-related } \\
\hline AMPK $\alpha_{1}($ phospho-T174) & polyclonal & $1: 50$ & Abcam, UK \\
\hline $14-3-3 \sigma$ & polyclonal & $1: 1,000$ & Abcam, UK \\
\hline PTEN & polyclonal & $1: 100$ & Invitrogen, Calif., USA \\
\hline Phospho-Akt (Ser473) & $736 \mathrm{E} 11$ & $1: 50$ & Cell Signaling, Mass., USA \\
\hline Phospho-mTOR (Ser2448) & 49F9 & $1: 50$ & Cell Signaling, Mass., USA \\
\hline Phospho-S6 (Ser235/236) & $\mathrm{D} 57.2 .2 \mathrm{~F}$ & $1: 50$ & Cell Signaling, Mass., USA \\
\hline \multicolumn{4}{|l|}{ Proliferation-related } \\
\hline Ki-67 & MIB-1 & $1: 150$ & DAKO, Denmark \\
\hline
\end{tabular}

EGFR = Epithelial growth factor receptor CK = cytokeratin; Glut-1 = glucose transporter 1 ; PTEN = phosphatase and tensin homolog.

(CAP) guidelines [21], using the following categories: $0=$ no immunostaining; $1+=$ weak, incomplete membranous staining, less than $10 \%$ of tumor cells; $2+=$ complete membranous staining, either uniform or weak in at least $10 \%$ of tumor cells, and $3+=$ uniform intense membranous staining in at least $30 \%$ of tumor cells. HER2 immunostaining was considered positive when strong (3+) membranous staining was observed, whereas cases with 0 and $1+$ were regarded as negative. The cases showing $2+$ HER2 expression were evaluated for HER2 amplification by fluorescent in situ hybridization (FISH). Immunohistochemical staining results of CK5/6 and EGFR were considered positive when more than $10 \%$ of tumor cells were stained. Immunohistochemical staining results of HIF- $1 \alpha$, Glut- 1 and Ki-67 were scored as the percentage of antibody-expressing tumor cells. Immunohistochemical staining results of 14-3-3 $\sigma$, PTEN, AMPK $\alpha_{1}$, phospho-Akt, phospho-mTOR, phospho-S6 and REDD1 were calculated by multiplying the percentage of tumor cells with antibody expression by the intensity of the expression $(1=$ weak, $2=\bmod$ erate and 3 = strong).

\section{Fluorescent in situ Hybridization}

The FISH analysis (Vysis PathVysion c-erbB2 probe and DAKO FISH histology accessory kit) was manually performed. In brief, sections from formalin-fixed, paraffin-embedded tissue were mounted on Superfrost Plus slides, deparaffinized in xylene and subsequently rehydrated in ethanol. Then, they were boiled for 10 min in pretreatment solution, incubated with pepsin solution for $10 \mathrm{~min}$, dehydrated in ethanol for $6 \mathrm{~min}$, and finally air dried. For hybridization, the buffered probe (Her-2/neu and centromere 17) was brought onto the slide and protected by a coverslip that was then sealed with rubber cement. For denaturation, the slides were heated to $82^{\circ} \mathrm{C}$ and incubated overnight at $45^{\circ} \mathrm{C}$ in a dark humidified chamber. The rubber cement and coverslip were then removed, and the slides were transferred to stringent wash buffer for $10 \mathrm{~min}$ at $65^{\circ} \mathrm{C}$. Afterward, they were dehydrated in ethanol for 6 min and air dried. Finally, they were counterstained with $4^{\prime}, 6$ diamidino-2-phenylindole. The signals were evaluated using an epifluorescence microscope (Olympus, Japan) equipped with a fluorescein, Cy3, and 4',6-diamidino-2-phenylindole filter set and a 100-watt mercury lamp. Counting was carried out according to the Vysis manual (the Her-2/neu gene appears orange, and centromere 17 green). We counted signals in at least 20 tumor nuclei in 2 separate regions of the tissue section according to the ASCO/ CAP guidelines. As proposed by the ASCO/CAP guidelines [21], an absolute HER2 gene copy number lower than 4 or HER2 gene/ chromosome 17 copy number ratio (HER2/Chr17 ratio) of less than 1.8 was considered HER2 negative, an absolute HER2 copy number between 4 and 6 or a HER2/Chr17 ratio between 1.8 and 2.2 was considered HER 2 equivocal, and an absolute HER 2 copy number greater than 6 or a HER2/Chr17 ratio higher than 2.2 was considered HER2 positive. Lymphocytes, fibroblasts and normal ductal epithelial cells were used as internal controls.

\section{Tumor Phenotype Classification}

Actually, the intrinsic breast cancer phenotype should be classified by gene expression profiling study, but in this study, we clas- 
Table 2. Clinicopathologic characteristics of patients according to breast cancer phenotype

\begin{tabular}{|c|c|c|c|c|c|c|}
\hline & $\begin{array}{l}\text { Total } \\
(\mathrm{n}=224)\end{array}$ & $\begin{array}{l}\text { TNBC } \\
(n=60)\end{array}$ & $\begin{array}{l}\text { HER2 } \\
(n=29)\end{array}$ & $\begin{array}{l}\text { Luminal A } \\
(\mathrm{n}=115)\end{array}$ & $\begin{array}{l}\text { Luminal B } \\
(\mathrm{n}=20)\end{array}$ & $\mathrm{p}$ \\
\hline Age, years & $48.7 \pm 10.8$ & $46.7 \pm 12.8$ & $48.2 \pm 9.3$ & $49.7 \pm 10.1$ & $49.6 \pm 9.9$ & 0.364 \\
\hline Histologic subtype & & & & & & 0.001 \\
\hline IDC, NOS & $212(94.6)$ & $51(85.0)$ & $26(89.7)$ & $115(100.0)$ & $20(100.0)$ & \\
\hline Medullary & $10(4.5)$ & $7(11.7)$ & $3(10.3)$ & & & \\
\hline Metaplastic & $2(0.9)$ & $2(3.3)$ & & & & \\
\hline Nuclear grade & & & & & & 0.000 \\
\hline 1 & $14(6.3)$ & $1(1.7)$ & & $12(10.4)$ & $1(5.0)$ & \\
\hline 2 & $126(56.3)$ & $24(40.0)$ & $12(41.4)$ & $77(67.0)$ & $13(65.0)$ & \\
\hline 3 & $84(37.5)$ & $35(58.3)$ & $17(58.6)$ & $26(22.6)$ & $6(30.0)$ & \\
\hline Histological grade & & & & & & 0.000 \\
\hline I & $32(14.3)$ & $4(6.7)$ & & $25(21.7)$ & $3(15.0)$ & \\
\hline II & $123(54.9)$ & $26(43.3)$ & $12(41.4)$ & $71(61.7)$ & $14(70.0)$ & \\
\hline III & $69(30.8)$ & $30(50.0)$ & $17(58.6)$ & $19(16.5)$ & $3(15.0)$ & \\
\hline \multicolumn{7}{|l|}{ ER status } \\
\hline Positive & $131(58.5)$ & & & & & \\
\hline Negative & $93(41.5)$ & & & & & \\
\hline \multicolumn{7}{|l|}{ PR status } \\
\hline Positive & $90(40.2)$ & & & & & \\
\hline Negative & $134(59.8)$ & & & & & \\
\hline \multicolumn{7}{|l|}{ HER2 status } \\
\hline Positive & $49(21.8)$ & & & & & \\
\hline Negative & $175(78.2)$ & & & & & \\
\hline CK5/6 & & & & & & 0.000 \\
\hline Positive & $17(7.6)$ & $15(25.0)$ & $2(6.9)$ & & & \\
\hline Negative & $207(92.4)$ & $45(75.0)$ & $27(93.1)$ & $115(100.0)$ & $20(100.0)$ & \\
\hline EGFR & & & & & & 0.000 \\
\hline Positive & $24(10.7)$ & $15(25.0)$ & $6(20.7)$ & $3(2.6)$ & & \\
\hline Negative & $200(89.3)$ & $45(75.0)$ & $23(79.3)$ & $112(97.4)$ & $20(100.0)$ & \\
\hline Lymph node metastasis & $97(43.3)$ & $19(31.7)$ & $12(41.4)$ & $55(47.8)$ & $11(55.0)$ & 0.146 \\
\hline Number of metastatic lymph nodes & $2.4 \pm 7.0$ & $1.0 \pm 2.2$ & $3.5 \pm 7.1$ & $2.4 \pm 8.0$ & $5.5 \pm 9.0$ & 0.077 \\
\hline Tumor recurrence & $24(10.7)$ & $4(6.7)$ & $4(13.8)$ & $12(10.4)$ & $4(20.0)$ & 0.582 \\
\hline Distant metastasis & $18(8.0)$ & $2(3.3)$ & $4(13.8)$ & $9(7.8)$ & $3(15.0)$ & 0.364 \\
\hline Patients' death & $13(5.8)$ & $4(6.7)$ & $4(13.8)$ & $4(3.5)$ & $1(5.0)$ & 0.191 \\
\hline Duration of clinical follow-up, months & $89.6 \pm 23.7$ & $85.8 \pm 24.1$ & $81.3 \pm 33.4$ & $93.3 \pm 19.9$ & $89.9 \pm 24.0$ & 0.090 \\
\hline \multicolumn{7}{|l|}{ Postoperative treatment } \\
\hline Chemotherapy & $191(85.3)$ & $55(91.7)$ & $28(96.6)$ & $88(76.5)$ & $20(100.0)$ & 0.002 \\
\hline Hormone therapy & $137(61.2)$ & $7(11.7)$ & $2(6.9)$ & $109(94.8)$ & $19(95.0)$ & 0.000 \\
\hline Radiotherapy & $66(29.5)$ & $21(35.0)$ & $10(34.5)$ & $28(24.3)$ & $7(35.0)$ & 0.395 \\
\hline
\end{tabular}

Values are numbers with percentages in parentheses or means \pm SD unless specified otherwise. IDC $=$ Infiltrating ductal carcinoma; NOS = not otherwise specified.

sified breast cancer phenotypes according to IHC and FISH results for ER, PR and HER2 as follows [22, 23], although there is some discrepancy between the intrinsic subtype according to IHC and the intrinsic subtype defined by gene profiling study: (a) luminal A type - ER or/and PR positive and HER2 negative; (b) luminal B type - ER or/and PR positive and HER2 overexpressed or/and amplified; (c) HER2 overexpression type - ER and PR negative and HER2 overexpressed or/and amplified, and (d) TNBC type - ER, PR and HER2 negative.

\section{Statistical Analysis}

Data were processed using SPSS for Windows, version 12.0 (SPSS Inc., Chicago, Ill., USA). Student's t and Fisher's exact tests were used to examine any difference in continuous and categorical variables, respectively. Significance was assumed when $\mathrm{p}<$ 0.05 . Kaplan-Meier survival curves and log rank statistics were employed to evaluate time to tumor metastasis and time to survival. Multivariate regression analysis was performed using Cox's proportional hazards model. 
Table 3. Immunohistochemical characteristics of hypoxia-mTOR-pathway-related protein according to breast cancer phenotype

\begin{tabular}{|c|c|c|c|c|c|c|c|c|c|}
\hline \multirow[t]{2}{*}{ Antibodies } & \multirow{2}{*}{$\begin{array}{l}\text { Total } \\
(\mathrm{n}=224)\end{array}$} & \multicolumn{5}{|c|}{ Tumor phenotype } & \multirow[t]{2}{*}{$\mathrm{p}^{1}$} & \multirow[t]{2}{*}{$\mathrm{p}^{2}$} & \multirow[t]{2}{*}{$\mathrm{p}^{3}$} \\
\hline & & $\begin{array}{l}\text { TNBC } \\
(\mathrm{n}=60)\end{array}$ & $\begin{array}{l}\text { HER2 } \\
(\mathrm{n}=29)\end{array}$ & $\begin{array}{l}\text { luminal A } \\
(\mathrm{n}=115)\end{array}$ & $\begin{array}{l}\text { luminal B } \\
(\mathrm{n}=20)\end{array}$ & $\begin{array}{l}\text { papilloma } \\
(\mathrm{n}=30)\end{array}$ & & & \\
\hline Glut-1 & $23.2 \pm 28.7$ & $39.5 \pm 30.8$ & $30.6 \pm 30.8$ & $14.3 \pm 23.9$ & $15.0 \pm 20.9$ & $41.6 \pm 15.9$ & 0.000 & 0.000 & 0.226 \\
\hline REDD1 & $16.6 \pm 28.0$ & $12.5 \pm 30.9$ & $21.9 \pm 25.7$ & $18.4 \pm 28.4$ & $11.0 \pm 17.4$ & $51.0 \pm 16.4$ & 0.000 & 0.307 & 0.000 \\
\hline HIF- $1 \alpha$ & $2.2 \pm 7.4$ & $3.1 \pm 6.7$ & $8.6 \pm 16.7$ & $0.3 \pm 1.5$ & $0.9 \pm 1.8$ & $3.5 \pm 2.6$ & 0.000 & 0.000 & 0.037 \\
\hline $14-3-3 \sigma$ & $52.4 \pm 33.7$ & $43.8 \pm 28.2$ & $53.7 \pm 34.1$ & $55.8 \pm 37.4$ & $56.5 \pm 20.0$ & $48.5 \pm 17.5$ & 0.133 & 0.142 & 0.278 \\
\hline $\mathrm{Ki}-67$ & $7.2 \pm 10.4$ & $13.2 \pm 13.2$ & $10.4 \pm 13.0$ & $3.9 \pm 6.6$ & $4.0 \pm 3.8$ & $4.2 \pm 1.8$ & 0.000 & 0.000 & 0.003 \\
\hline PTEN & $13.2 \pm 25.4$ & $9.6 \pm 22.0$ & $17.2 \pm 32.7$ & $15.2 \pm 26.2$ & $6.5 \pm 14.9$ & $46.0 \pm 20.9$ & 0.000 & 0.262 & 0.000 \\
\hline Phospho-Akt (Ser473) & $5.9 \pm 19.0$ & $8.0 \pm 23.7$ & $13.4 \pm 32.6$ & $3.4 \pm 11.0$ & $3.5 \pm 8.7$ & $7.2 \pm 7.4$ & 0.084 & 0.058 & 0.525 \\
\hline Phospho-mTOR (Ser2448) & $87.7 \pm 78.5$ & $63.0 \pm 61.6$ & $109.3 \pm 87.2$ & $96.7 \pm 82.0$ & $79.2 \pm 76.4$ & $59.3 \pm 31.1$ & 0.005 & 0.019 & 0.003 \\
\hline Phospho-S6 (Ser235/236) & $41.0 \pm 58.2$ & $51.5 \pm 56.5$ & $72.5 \pm 79.9$ & $25.6 \pm 44.3$ & $52.5 \pm 72.2$ & $35.6 \pm 18.0$ & 0.000 & 0.000 & 0.048 \\
\hline AMPK $\alpha_{1}$ (phospho-T174) & $45.0 \pm 33.5$ & $40.9 \pm 31.5$ & $52.0 \pm 34.7$ & $46.4 \pm 35.2$ & $39.5 \pm 26.2$ & $48.0 \pm 20.4$ & 0.571 & 0.405 & 0.228 \\
\hline
\end{tabular}

Values denote means \pm SD unless stated otherwise. $p$ values set in italics are significant.

${ }^{1} \mathrm{p}$ value calculated for all 4 breast cancer phenotypes and papilloma.

${ }^{2} \mathrm{p}$ value calculated for all 4 tumor phenotypes.

${ }^{3} \mathrm{p}$ value calculated only for TNBC and HER2 types as well as for papilloma.

\section{Results}

\section{Clinicopathologic Features of Patients according to}

Breast Cancer Phenotype

Table 2 shows the clinicopathologic characteristics of the patients. Forty-three patients (19.2\%) did not undergo clinical follow-up after breast surgery. When breast cancer was classified according to ER, PR and HER2 status, most medullary carcinomas (70\%) and all metaplastic carcinomas $(100 \%)$ were of the TNBC type $(p=0.001)$. The nuclear grade and histological grade were higher in TNBC and HER 2 overexpression types than in luminal A and B types $(\mathrm{p}=0.000)$. Most CK5/6-expressing $(88.2 \%)$ or EGFR-expressing (62.5\%) breast cancers were of the TNBC type $(\mathrm{p}<0.000)$. Both CK5/6 and EGFR positivity were noted in 7 cases ( 5 cases: TNBC type; 2 cases: HER 2 type). The number of metastatic lymph nodes was highest in the luminal B type $(5.5 \pm 9.0)$ and lowest in the TNBC type $(1.0 \pm 2.2 ; \mathrm{p}=0.077)$.

\section{Comparison of Immunohistochemical Features according to Breast Cancer Phenotype}

Table 3 and figure 1 demonstrate the immunohistochemical results for the hypoxia-mTOR-pathway-related protein according to breast cancer phenotype. Glut- 1 and HIF-1 $\alpha$ were more highly expressed in the TNBC and HER2 overexpression types and papilloma than in the luminal A and B types ( $p<0.000)$ (fig. $2 a)$. HIF- $1 \alpha$ expression was noted in the cytoplasm and nucleus in the
TNBC and HER 2 overexpression types, but only in nuclei in papilloma (fig. 1). REDD1 and PTEN expression was higher in papilloma than in any other breast cancer phenotypes ( $\mathrm{p}<0.000)$ (fig. 2b). The expression of Ki-67 was higher in the TNBC and HER2 overexpression types than in other phenotypes and papilloma $(\mathrm{p}<0.000)$. Phospho-mTOR and phospho-S6 were most highly expressed in the HER 2 overexpression type $(\mathrm{p}=0.005$ and $\mathrm{p}<0.000$, respectively). The statistical analyses were only performed for the 224 cases of breast cancer, not for the 30 cases of papilloma. In addition, the statistical analyses only aiming at the TNBC and HER2 overexpression types and papillomas were performed because these 3 groups showed a similar hypoxic tumor environment known from the histological features and high Glut-1 expression. The corresponding statistical $\mathrm{p}$ values are also presented in table 3 . The expression of REDD1 is higher in papilloma than in the TNBC and HER2 overexpression types $(\mathrm{p}<0.000)$, and the expression of HIF- $1 \alpha$ is highest in the HER2 overexpression type $(\mathrm{p}=0.037)$. PTEN expression is higher in papilloma than in the TNBC and HER2 overexpression types $(\mathrm{p}<0.000)$, but phospho-mTOR and phospho-S6 expression is lower ( $\mathrm{p}=$ 0.003 and 0.048 , respectively).

Table 4 shows the correlation of CK5/6 with EGFR expression with clinicopathologic and hypoxia-mTORpathway-related immunohistochemical results in the TNBC type. CK5/6-positive TNBC showed higher Glut-1 expression $(p=0.013)$ and lower phospho-mTOR expres- 


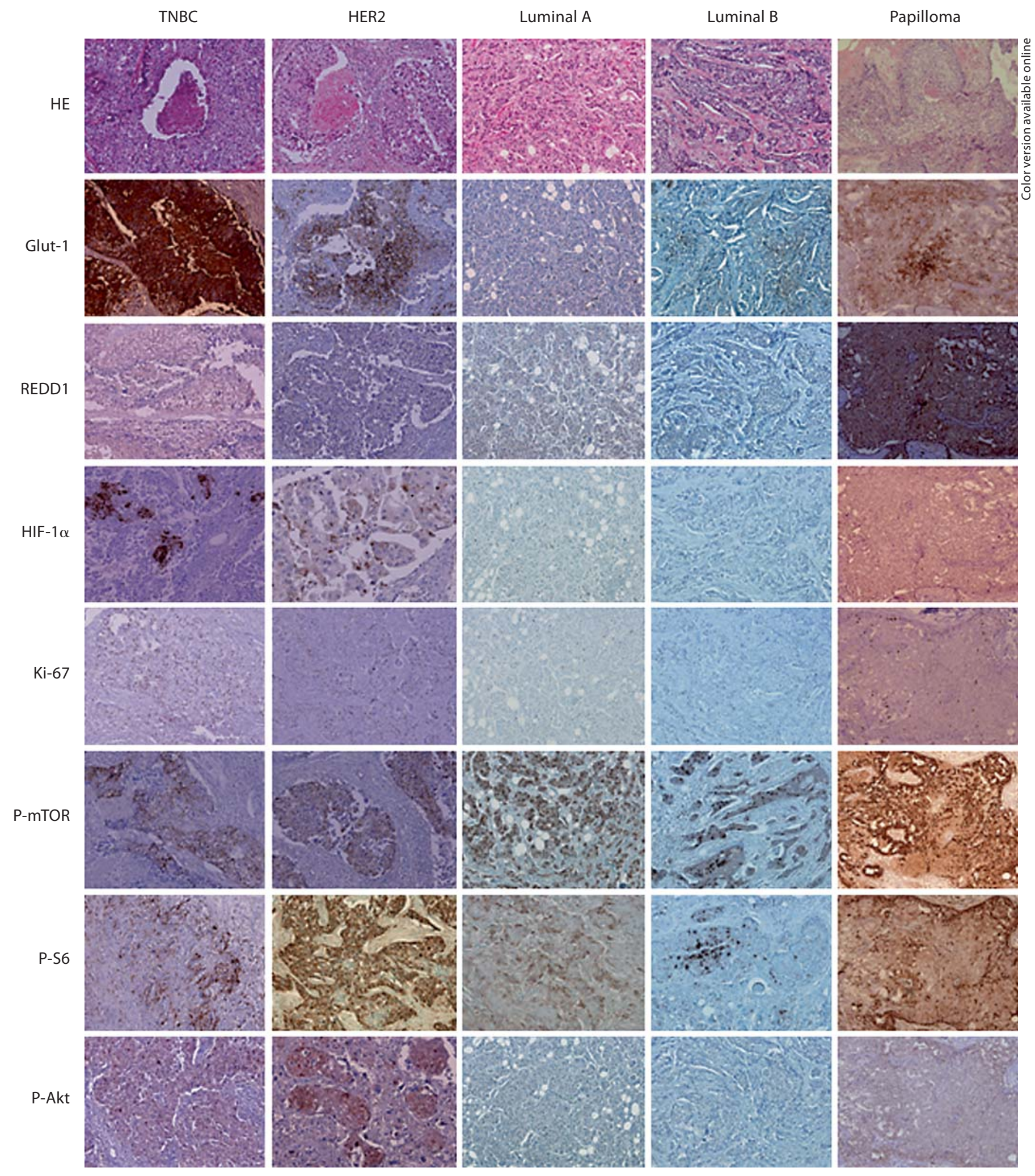



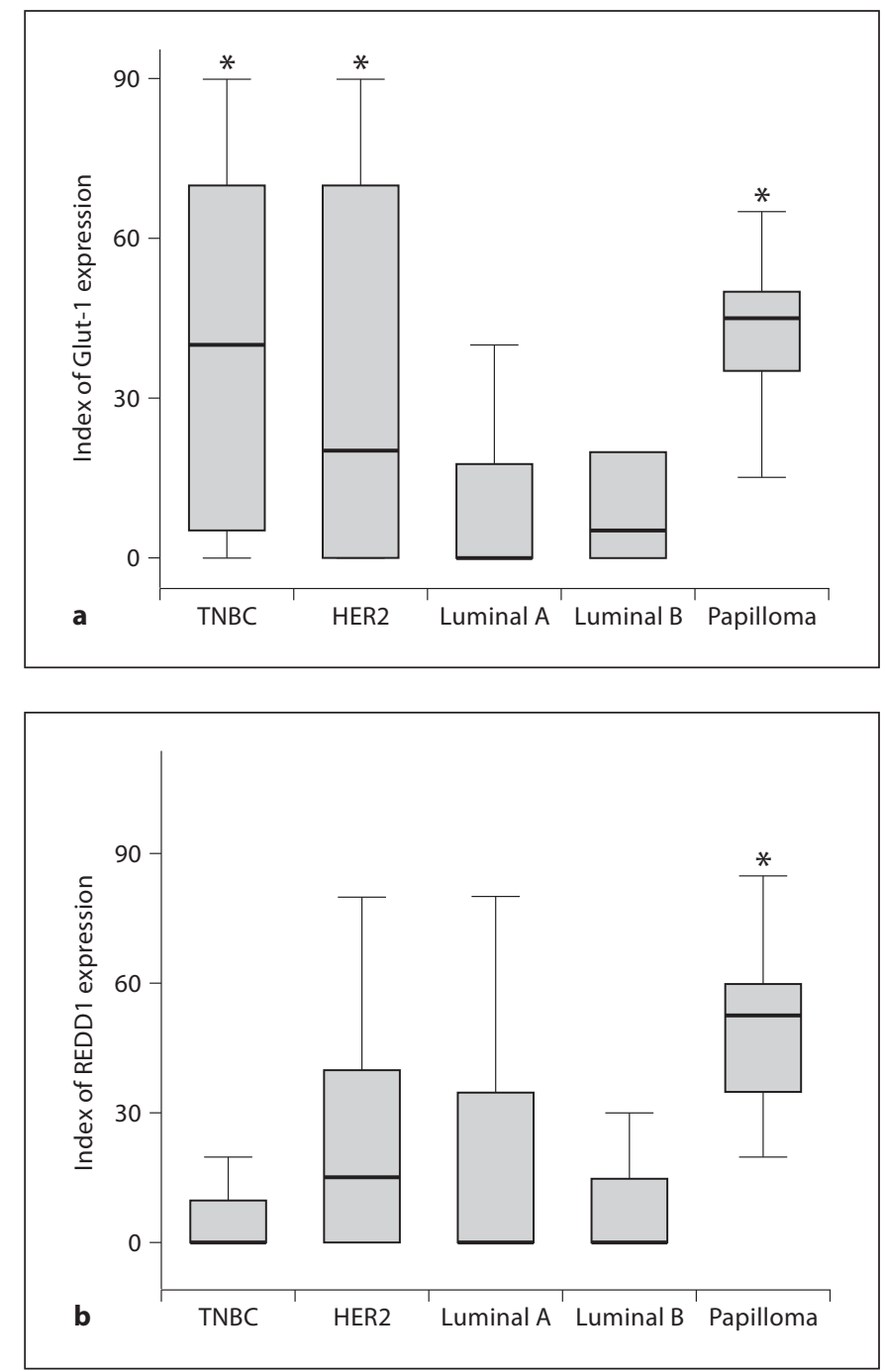

Fig. 2 Comparison between index of Glut-1 expression (a) and REDD1 expression (b) according to breast cancer phenotype. ${ }^{*} \mathrm{p}<0.05$.

Fig. 1. Histological and immunohistochemical features of breast cancer according to tumor phenotypes for ER, PR and HER2 status. The TNBC and HER2 overexpression types and papilloma show areas of geographic tumor cell necrosis, but the luminal A and $\mathrm{B}$ types demonstrate no tumor cell necrosis. The TNBC and HER2 overexpression types and papilloma show a more increased expression of Glut-1 than the luminal A and B types, showing a more hypoxic tumor environment. However, the expression of REDD1, a hypoxia-related protein, is not different among breast cancer phenotypes. In contrast, papilloma shows diffuse expression of REDD1. The expression of HIF-1 $\alpha$, Ki-67 and phosphoAkt is higher in the TNBC and HER2 overexpression types than in the luminal A and B types. The expression of phospho-mTOR and phospho-S6 is highest in the HER2 overexpression type among breast cancer phenotypes.

REDD1 Regulation in Breast Cancer sion $(\mathrm{p}=0.049)$ than CK5/6-negative TNBC. CK5/6-positive TNBC showed lower REDD1 expression than CK5/6negative TNBC, but without significance $(\mathrm{p}=0.188)$. EGFR-positive TNBC demonstrated higher expression of REDD1 $(p=0.024)$ and AMPK $\alpha_{1}(p=0.021)$ than EGFR-negative TNBC. In addition, EGFR-positive TNBC showed higher Glut-1 expression than EGFR-negative TNBC, but without significance $(\mathrm{p}=0.063)$.

\section{Impact of Immunohistochemical Results of Hypoxia-mTOR-Pathway-Related Protein on Tumor \\ Recurrence, Distant Metastasis and Patient Survival}

Table 5 shows the influence of immunohistochemical staining results on tumor recurrence, distant metastasis and patient survival. Breast cancers with tumor recurrence $(p=0.033)$, distant metastasis $(p=0.004)$ or patient death $(\mathrm{p}=0.001)$ showed a higher incidence of HIF- $1 \alpha$ expression than breast cancer without tumor recurrence, distant metastasis or patient death. There was a trend that breast cancer which resulted in tumor recurrence, distant metastasis or patient death had a higher expression of phospho-mTOR and a lower expression of phospho-Akt than breast cancer without recurrence, but there was no significance.

Table 6 demonstrates the univariate analyses of the immunohistochemical results of the hypoxia-mTORpathway-related protein with regard to time to diseasefree survival (DFS) and overall survival (OS). The immunohistochemical results of hypoxia-mTOR-pathwayrelated protein were categorized according to the immunohistochemical scores as shown in table 6. The results of the univariate analyses of immunohistochemical markers with regard to time to DFS revealed significance for HIF-1 $\alpha(\mathrm{p}=0.003)$ (fig. 3a) and radiotherapy ( $\mathrm{p}=$ 0.003). That is, breast cancer with HIF- $1 \alpha$ expression or radiotherapy showed shorter DFS times than breast cancer without HIF-1 $\alpha$ expression or radiotherapy. A multivariate Cox proportional hazards model analysis also showed significance for HIF- $1 \alpha(\mathrm{p}=0.018$; odds ratio: 7.6$)$ and radiotherapy $(\mathrm{p}=0.007$; odds ratio: 3.0$)$. The results of the univariate analyses of immunohistochemical markers with regard to time to OS revealed significance for 3 parameters: radiotherapy $(\mathrm{p}<0.000)$, Glut-1 ( $\mathrm{p}=$ $0.047)$ and HIF- $1 \alpha(p=0.000)$ (fig. 3b). In the multivariate Cox regression analysis, HIF- $1 \alpha(\mathrm{p}=0.002$; odds ratio: 13.7) and radiotherapy ( $\mathrm{p}=0.004$; odds ratio: 5.6$)$ showed significance. 
Table 4. Correlation between CK5/6 and EGFR expression status with clinicopathologic and hypoxia-mTOR-pathway-related immunohistochemical results in TNBC

$\begin{array}{lllll}\begin{array}{l}\text { CK5/6 positive } \\ (\mathrm{n}=15)\end{array} & \begin{array}{l}\text { CK5/6 negative } \\ (\mathrm{n}=45)\end{array} & \mathrm{p} & \begin{array}{l}\text { EGFR positive } \\ (\mathrm{n}=15)\end{array} & \begin{array}{l}\text { EGFR negative } \\ (\mathrm{n}=45)\end{array}\end{array}$

\begin{tabular}{|c|c|c|c|c|c|c|}
\hline \multicolumn{7}{|c|}{ Clinicopathologic parameters TNBC $(n=60)$} \\
\hline \multicolumn{3}{|c|}{ Nuclear grade } & \multicolumn{3}{|l|}{0.369} & \multirow[t]{4}{*}{0.672} \\
\hline 1 & & $1(2.2)$ & & & $1(2.2)$ & \\
\hline 2 & $4(26.7)$ & $20(44.4)$ & & $5(33.3)$ & $19(42.2)$ & \\
\hline 3 & $11(73.3)$ & $24(53.3)$ & & $10(66.7)$ & $25(55.6)$ & \\
\hline \multirow{2}{*}{\multicolumn{2}{|c|}{$\begin{array}{l}\text { Histological grade } \\
\text { I }\end{array}$}} & & \multicolumn{3}{|l|}{0.489} & 0.953 \\
\hline & & $4(8.9)$ & & $1(6.7)$ & $3(6.7)$ & \\
\hline II & $7(46.7)$ & $19(42.2)$ & & $6(40.0)$ & $20(44.4)$ & \\
\hline III & $8(53.3)$ & $22(48.9)$ & & $8(53.3)$ & $22(48.9)$ & \\
\hline Lymph node metastasis & $2(13.3)$ & $17(37.8)$ & 0.078 & $6(40.0)$ & $13(28.9)$ & 0.423 \\
\hline Tumor recurrence & $1(6.7)$ & $3(6.7)$ & 0.931 & $1(6.7)$ & $3(6.7)$ & 0.931 \\
\hline Distant metastasis & $1(6.7)$ & $1(2.2)$ & 0.448 & $1(6.7)$ & $1(2.2)$ & 0.448 \\
\hline Patients' death & $1(6.7)$ & $3(6.7)$ & 0.931 & $1(6.7)$ & $3(6.7)$ & 0.931 \\
\hline \multicolumn{7}{|c|}{ Immunohistochemical parameters TNBC $(n=60)$} \\
\hline Glut-1 & $56.3 \pm 31.6$ & $33.8 \pm 28.8$ & 0.013 & $52.3 \pm 26.9$ & $35.2 \pm 31.2$ & 0.063 \\
\hline REDD1 & $3.3 \pm 10.4$ & $15.5 \pm 34.8$ & 0.188 & $28.0 \pm 53.4$ & $7.3 \pm 16.2$ & 0.024 \\
\hline HIF- $1 \alpha$ & $2.0 \pm 3.6$ & $3.5 \pm 7.4$ & 0.441 & $5.6 \pm 11.1$ & $2.3 \pm 4.2$ & 0.095 \\
\hline $14-3-3 \sigma$ & $52.6 \pm 34.9$ & $40.8 \pm 25.4$ & 0.164 & $52.0 \pm 37.4$ & $41.1 \pm 24.4$ & 0.199 \\
\hline Ki-67 & $11.8 \pm 9.7$ & $13.6 \pm 14.2$ & 0.640 & $14.7 \pm 12.4$ & $12.6 \pm 13.6$ & 0.609 \\
\hline PTEN & $16.0 \pm 30.6$ & $7.5 \pm 18.3$ & 0.202 & $5.3 \pm 12.4$ & $11.1 \pm 24.4$ & 0.385 \\
\hline Phospho-Akt (Ser473) & $6.6 \pm 16.7$ & $8.4 \pm 25.7$ & 0.804 & $3.3 \pm 10.4$ & $9.5 \pm 26.6$ & 0.383 \\
\hline Phospho-mTOR (Ser2448) & $36.0 \pm 46.6$ & $72.0 \pm 63.7$ & 0.049 & $51.0 \pm 61.5$ & $67.0 \pm 61.7$ & 0.388 \\
\hline Phospho-S6 (Ser235/236) & $44.3 \pm 51.6$ & $53.8 \pm 58.3$ & 0.575 & $69.3 \pm 67.6$ & $45.6 \pm 51.7$ & 0.160 \\
\hline AMPK $\alpha_{1}$ (phospho-T174) & $49.3 \pm 24.9$ & $38.1 \pm 33.1$ & 0.235 & $57.0 \pm 36.7$ & $35.5 \pm 28.0$ & 0.021 \\
\hline
\end{tabular}

Values are numbers with percentages in parentheses or means \pm SD unless specified otherwise. Significant $p$ values are set in italics.

Table 5. Impact of immunohistochemical results for hypoxia-mTOR-pathway-related protein on tumor recurrence, distant metastasis and patient survival

\begin{tabular}{|c|c|c|c|c|c|c|c|c|c|}
\hline & \multicolumn{2}{|c|}{ Tumor recurrence $(\mathrm{n}=182)$} & \multirow[t]{2}{*}{$\mathrm{p}$} & \multicolumn{2}{|c|}{ Distant metastasis $(\mathrm{n}=182)$} & \multirow[t]{2}{*}{$\mathrm{p}$} & \multicolumn{2}{|c|}{ Patient survival $(\mathrm{n}=182)$} & \multirow[t]{2}{*}{$\mathrm{p}$} \\
\hline & $\begin{array}{l}\text { present } \\
(\mathrm{n}=24)\end{array}$ & $\begin{array}{l}\text { absent } \\
(\mathrm{n}=158)\end{array}$ & & $\begin{array}{l}\text { present } \\
(\mathrm{n}=18)\end{array}$ & $\begin{array}{l}\text { absent } \\
(\mathrm{n}=164)\end{array}$ & & $\begin{array}{l}\text { death } \\
(\mathrm{n}=13)\end{array}$ & $\begin{array}{l}\text { survival } \\
(\mathrm{n}=169)\end{array}$ & \\
\hline Glut-1 & $19.1 \pm 23.1$ & $23.0 \pm 29.4$ & 0.542 & $17.7 \pm 21.5$ & $23.0 \pm 29.3$ & 0.463 & $26.1 \pm 26.3$ & $22.2 \pm 28.8$ & 0.635 \\
\hline REDD1 & $15.0 \pm 23.5$ & $17.6 \pm 29.6$ & 0.675 & $16.6 \pm 23.7$ & $17.3 \pm 29.4$ & 0.921 & $18.4 \pm 26.0$ & $17.2 \pm 29.1$ & 0.882 \\
\hline HIF- $1 \alpha$ & $5.3 \pm 16.0$ & $1.7 \pm 5.3$ & 0.033 & $7.1 \pm 18.3$ & $1.6 \pm 5.2$ & 0.004 & $9.2 \pm 21.3$ & $1.6 \pm 5.1$ & 0.001 \\
\hline $14-3-3 \sigma$ & $47.9 \pm 27.6$ & $54.3 \pm 33.0$ & 0.353 & $50.0 \pm 29.5$ & $54.0 \pm 32.7$ & 0.615 & $42.3 \pm 30.3$ & $54.5 \pm 32.4$ & 0.191 \\
\hline Ki-67 & $5.5 \pm 9.0$ & $6.8 \pm 9.8$ & 0.568 & $6.1 \pm 10.3$ & $6.7 \pm 9.7$ & 0.826 & $9.5 \pm 12.6$ & $6.4 \pm 9.5$ & 0.269 \\
\hline PTEN & $8.7 \pm 18.2$ & $14.0 \pm 27.1$ & 0.356 & $10.0 \pm 20.8$ & $13.7 \pm 26.7$ & 0.568 & $8.4 \pm 16.7$ & $13.7 \pm 26.7$ & 0486 \\
\hline Phospho-Akt (Ser473) & $1.2 \pm 4.4$ & $7.3 \pm 21.9$ & 0.179 & $1.6 \pm 5.1$ & $7.0 \pm 21.6$ & 0.293 & $1.5 \pm 5.5$ & $6.9 \pm 21.3$ & 0.366 \\
\hline Phospho-mTOR (Ser2448) & $105.4 \pm 87.9$ & $89.3 \pm 79.1$ & 0.361 & $121.6 \pm 86.1$ & $88.1 \pm 79.1$ & 0.092 & $122.3 \pm 79.9$ & $89.0 \pm 80.0$ & 0.150 \\
\hline Phospho-S6 (Ser235/236) & $36.4 \pm 43.5$ & $39.7 \pm 60.3$ & 0.796 & $41.6 \pm 41.9$ & $39.0 \pm 59.9$ & 0.859 & $40.3 \pm 44.9$ & $39.2 \pm 59.3$ & 0.947 \\
\hline AMPK $\alpha_{1}$ (phospho-T174) & $38.3 \pm 30.5$ & $46.4 \pm 33.5$ & 0.266 & $43.3 \pm 32.1$ & $45.6 \pm 33.4$ & 0.784 & $40.7 \pm 29.5$ & $45.7 \pm 33.5$ & 0.605 \\
\hline
\end{tabular}

Values denote means \pm SD unless specified otherwise. Significant $\mathrm{p}$ values are set in italics. 
Table 6. Univariate analyses of treatment modalities and various immunohistochemical factors in breast cancers with regard to time to recurrence-free survival and OS by log rank test

\begin{tabular}{|c|c|c|c|c|c|c|c|}
\hline & \multicolumn{3}{|c|}{ Patients $(\mathrm{n}=182), \mathrm{n}$} & \multicolumn{2}{|c|}{ Recurrence-free survival } & \multicolumn{2}{|l|}{ OS } \\
\hline & cases & $\begin{array}{l}\text { tumor } \\
\text { recurrence }\end{array}$ & $\begin{array}{l}\text { patient } \\
\text { death }\end{array}$ & $\begin{array}{l}\text { mean survival } \\
\text { months }\end{array}$ & $\mathrm{p}$ & $\begin{array}{l}\text { mean survival } \\
\text { months }\end{array}$ & $\mathrm{p}$ \\
\hline Chemotherapy & & & & & 0.913 & & 0.145 \\
\hline No & 24 & 3 & 0 & $105(94-116)$ & & $\mathrm{n} / \mathrm{a}$ & \\
\hline Yes & 158 & 21 & 13 & $105(101-109)$ & & $109(106-113)$ & \\
\hline Hormone therapy & & & & & 0.952 & & 0.125 \\
\hline No & 65 & 8 & 7 & $102(94-109)$ & & $105(98-111)$ & \\
\hline Yes & 117 & 16 & 6 & $106(101-110)$ & & $112(110-115)$ & \\
\hline Radiotherapy & & & & & 0.003 & & 0.000 \\
\hline No & 126 & 11 & 4 & $109(105-112)$ & & $113(111-115)$ & \\
\hline Yes & 56 & 13 & 9 & $94(85-103)$ & & $101(94-108)$ & \\
\hline Glut-1 & & & & & 0.829 & & 0.047 \\
\hline 0 & 80 & 11 & 6 & $104(98-110)$ & & $110(106-114)$ & \\
\hline $1-30$ & 46 & 5 & 0 & $108(102-114)$ & & $\mathrm{n} / \mathrm{a}$ & \\
\hline$>30$ & 56 & 8 & 7 & $102(94-109)$ & & $105(99-111)$ & \\
\hline REDD1 & & & & & 0.696 & & 0.968 \\
\hline 0 & 110 & 16 & 8 & $102(97-107)$ & & $108(105-112)$ & \\
\hline $1-30$ & 32 & 3 & 2 & $108(101-116)$ & & $111(106-117)$ & \\
\hline$>30$ & 40 & 5 & 3 & $105(97-114)$ & & $109(102-116)$ & \\
\hline HIF- $1 \alpha$ & & & & & 0.003 & & 0.000 \\
\hline 0 & 149 & 19 & 10 & $105(101-110)$ & & $111(108-113)$ & \\
\hline $1-30$ & 30 & 3 & 1 & $106(99-114)$ & & $110(106-115)$ & \\
\hline$>30$ & 3 & 2 & 2 & $54(12-97)$ & & $62(25-98)$ & \\
\hline $14-3-3 \sigma$ & & & & & 0.210 & & 0.343 \\
\hline$<100$ & 172 & 24 & 13 & $104(100-109)$ & & $110(107-113)$ & \\
\hline 100-200 & 10 & 0 & 0 & $\mathrm{n} / \mathrm{a}$ & & $\mathrm{n} / \mathrm{a}$ & \\
\hline$>200$ & 0 & 0 & 0 & $\mathrm{n} / \mathrm{a}$ & & $\mathrm{n} / \mathrm{a}$ & \\
\hline Ki-67 & & & & & 0.668 & & 0.806 \\
\hline$<30$ & 170 & 23 & 12 & $105(101-109)$ & & $110(108-113)$ & \\
\hline$\geq 30$ & 12 & 1 & 1 & $96(82-110)$ & & $96(83-109)$ & \\
\hline PTEN & & & & & 0.705 & & 0.170 \\
\hline 0 & 123 & 15 & 8 & $106(101-110)$ & & $111(108-114)$ & \\
\hline $1-30$ & 27 & 7 & 4 & $90(77-103)$ & & $98(88-108)$ & \\
\hline$>30$ & 32 & 2 & 1 & $107(102-112)$ & & $108(103-112)$ & \\
\hline Phospho-Akt (Ser473) & & & & & 0.329 & & 0.572 \\
\hline 0 & 147 & 22 & 12 & $103(98-108)$ & & $109(106-113)$ & \\
\hline $1-30$ & 24 & 2 & 1 & $109(104-113)$ & & $111(108-113)$ & \\
\hline$>30$ & 11 & 0 & 0 & $\mathrm{n} / \mathrm{a}$ & & $\mathrm{n} / \mathrm{a}$ & \\
\hline Phospho-mTOR (Ser2448) & & & & & 0.625 & & 0.481 \\
\hline$<100$ & 107 & 14 & 7 & $104(99-110)$ & & $110(107-114)$ & \\
\hline $100-200$ & 41 & 4 & 2 & $106(100-112)$ & & $109(104-113)$ & \\
\hline$>200$ & 34 & 6 & 4 & $103(94-112)$ & & $108(100-115)$ & \\
\hline Phospho-S6 (Ser235/236) & & & & & 0.189 & & 0.449 \\
\hline$<100$ & 159 & 20 & 11 & $106(101-110)$ & & $110(108-113)$ & \\
\hline $100-200$ & 16 & 4 & 2 & $90(74-105)$ & & $98(86-110)$ & \\
\hline$>200$ & 7 & 0 & 0 & $\mathrm{n} / \mathrm{a}$ & & $\mathrm{n} / \mathrm{a}$ & \\
\hline AMPK $\alpha_{1}$ (phospho-T174) & & & & & 0.388 & & 0.515 \\
\hline$<100$ & 177 & 24 & 13 & $105(101-109)$ & & $110(107-113)$ & \\
\hline $100-200$ & 5 & 0 & 0 & $\mathrm{n} / \mathrm{a}$ & & $\mathrm{n} / \mathrm{a}$ & \\
\hline$>200$ & 0 & 0 & 0 & $\mathrm{n} / \mathrm{a}$ & & $\mathrm{n} / \mathrm{a}$ & \\
\hline
\end{tabular}

Values in parentheses denote 95\% CI. Significant p values are set in italics. n/a = Not available. 
Fig. 3. DFS (a) and OS curves (b) according to the extent of HIF-1 $\alpha$ expression in breast cancer.

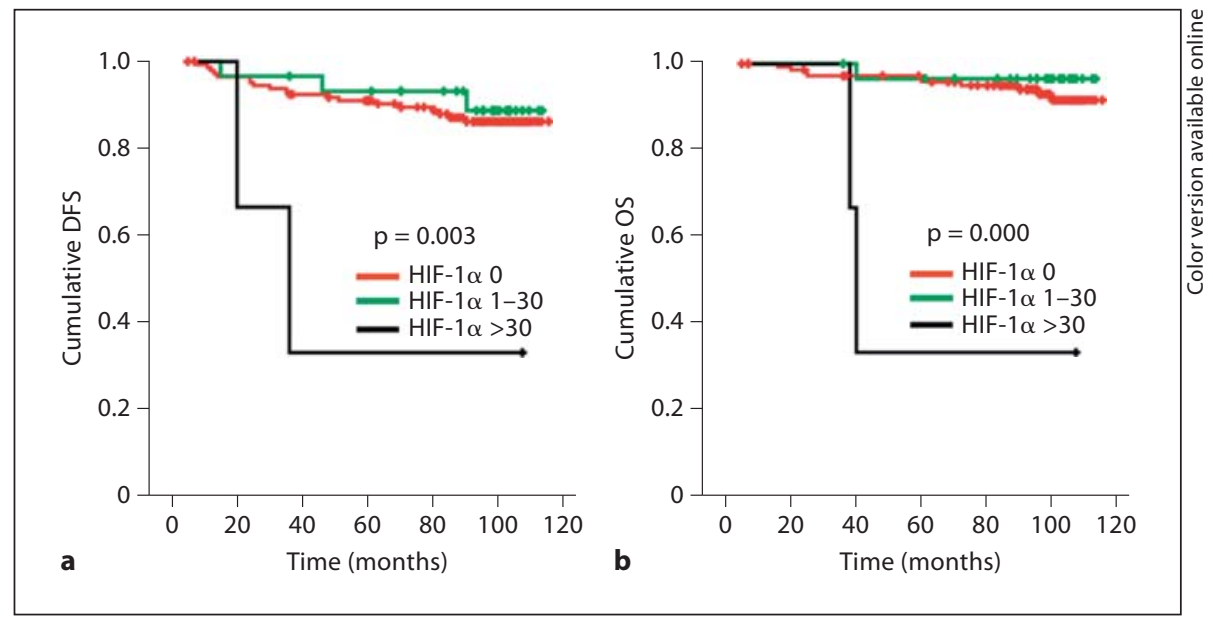

\section{Discussion}

This study was designed to investigate the difference in hypoxia mTOR pathway regulation according to breast cancer phenotypes by IHC and FISH results. The TNBC and HER2 overexpression types and papilloma showed a higher expression of Glut-1, hypoxia-regulated glucose transporter, than the luminal $A$ and $B$ types $(p=0.000)$. This finding revealed that TNBC, the HER2 overexpression type and papilloma were exposed to a more hypoxic tumor environment, which was consistent with histological features (fig. 1, HE). However, REDD1, which is known to show increased expression in normal cells under hypoxia, was less expressed in TNBC and the HER2 overexpression type than in papilloma $(\mathrm{p}=0.000)$. REDD1 inhibits cell proliferation and survival by TSC1/ TSC2-complex-mediated downregulation of the mTOR pathway by 14-3-3 $\sigma$ shuttling [15]. Therefore, in spite of the hypoxic tumor environment, tumor cell proliferation and survival were not inhibited in TNBC and the HER2 overexpression type due to downregulation of REDD1. Moreover, the proliferation activity of TNBC and the HER2 overexpression type was higher than that of other breast cancer phenotypes or papilloma according to the results of Ki-67 IHC ( $\mathrm{p}=0.000)$. The previously mentioned in vitro cell line study demonstrated that a loss of REDD1 signaling caused by mutant REDD1 promoted cell proliferation and anchorage-independent growth under hypoxic conditions by mTOR dysregulation. An in vivo mouse study showed that a loss of REDD1 caused tumorigenesis [15]. In particular, 30\% of human breast cancers were reported to show downregulation of REDD1, but the status of REDD1 expression has not been investi- gated according to breast cancer phenotypes [15]. In this study, the proportion of TNBC and HER2 overexpression types with lower expression of REDD1 under hypoxia was $40 \%$ of breast cancers, which is a similar proportion to that of human breast cancer with REDD1 downregulation in the previous study. This study classified breast cancer phenotypes according to ER, PR and HER2 status by using IHC and FISH. We believe that TNBC and the HER2 overexpression type in this study usually correspond to the basal-like, HER2 overexpression and normal breast-like types in gene profiling studies. The incidence of the basal-like, HER2 overexpression and normal breast-like types in a gene profiling study was 18,14 and $7.7 \%$, respectively [2]. Therefore, the incidence of these 3 breast cancer phenotypes (39.7\%) was similar to that of TNBC and the HER2 overexpression type in this study (40\%).

REDD1, which serves as a tumor suppressor, is regulated by HIF- $1 \alpha$ or AMPK on the transcription level, but the functioning mechanism between HIF-1 $\alpha$ and AMPK is different. HIF-1 $\alpha$ causes REDD1 expression by activation of the phosphatidylinositol 3-kinase/Akt signaling pathway under acute hypoxia and high cell density [24]. However, AMPK is activated and causes REDD1 expression independent of HIF- $1 \alpha$ when ATP depletion occurs due to chronic hypoxia [18]. Posttranslational regulation of REDD1 is manipulated by CUL4A (Cullin 4A)-DDB1 (DNA damage-binding protein 1)-ROC1 (regulator of cullins 1) ubiquitin ligase, which rapidly degrades REDD1 during the cellular recovery from hypoxic stress, resulting in restoration of the mTOR signaling pathway [25]. Because so many components are engaged in the regulation of REDD1, the exact mechanism of REDD1 down- 
regulation in TNBC and the HER2 overexpression type could not be found in this study. However, this study showed that the expression rate of AMPK $\alpha_{1}$ did not differ among breast cancer phenotypes, but that the expression of HIF- $1 \alpha$ was higher in TNBC and the HER 2 overexpression type $(\mathrm{p}=0.000)$. Although REDD1 is induced by HIF- $1 \alpha$, induced REDD1 regulates HIF-1 $\alpha$ by negative feedback control via ubiquitin-proteasome-mediated degradation by a reactive-oxygen-species-dependent mechanism in mitochondria [26]. Therefore, when REDD1 is downregulated, the expression of HIF- $1 \alpha$ is enhanced as there is no negative feedback to HIF- $1 \alpha$, which in turn promotes tumorigenesis. These features were also observed in this study. In particular, our study demonstrated a significant correlation between the expression of HIF- $1 \alpha$ and DFS ( $p=0.003)$ and OS $(p=0.000)$. This correlation was concurrent with previous studies which reported that HIF-1 $\alpha$ expression was associated with reduced DFS, reduced OS, high-grade tumor, ER loss, high Ki-67 expression and HER2 gene amplification [27-29].

Interestingly, benign papilloma also demonstrated a higher expression of HIF- $1 \alpha$ than luminal A and B types $(p=0.000)$, but the HIF- $1 \alpha$ expression pattern of benign papilloma was different from that of TNBC and the HER2 overexpression type. While papilloma showed HIF-1 $\alpha$ expression mostly in nuclei, TNBC and the HER2 overexpression type demonstrated HIF-1 $\alpha$ expression in nuclei and cytoplasm. In TNBC and the HER2 overexpression type, expressed HIF-1 $\alpha$ protein by hypoxia was not degraded by the ubiquitin-proteasome system due to REDD1 downregulation [26], resulting in HIF-1 $\alpha$ stabilization and expression in cytoplasm and nuclei. On the other hand, in papilloma, HIF-1 $\alpha$ protein induced by acute hypoxia was degraded by the ubiquitin-proteasome system due to normally expressed REDD1, resulting in HIF-1 $\alpha$ protein expression not in cytoplasm, but only in nuclei.

The expression rate of HIF- $1 \alpha$ was higher in the HER2 overexpression type than in TNBC $(\mathrm{p}=0.037)$. Because the expression of HIF-1 $\alpha$ protein is enhanced by the HER2 signaling pathway in human breast cancer [30], eventually, in the HER2 overexpression type, the expression of HIF-1 $\alpha$ protein is induced not only by enhanced intratumoral hypoxia, but also by HER 2 signaling activation, which is also compatible with this study.

In conclusion, among breast cancer phenotypes, the HER2 overexpression and TNBC types showed downregulation of REDD1 even in a hypoxic tumor environment and demonstrated promoted tumor cell proliferation and survival in a hypoxic tumor environment by disinhibition of the mTOR pathway and HIF- $1 \alpha$ stabilization via REDD1 downregulation.

\section{Acknowledgment}

This study was supported by a faculty research grant of the Yonsei University College of Medicine for 2009 (6-2009-0110).

\section{References}

1 Perou CM, Sørlie T, Eisen MB, van de Rijn M, Jeffrey SS, Rees CA, Pollack JR, Ross DT, Johnsen H, Akslen LA, Fluge O, Pergamenschikov A, Williams C, Zhu SX, Lønning PE, Børresen-Dale AL, Brown PO, Botstein D: Molecular portraits of human breast tumours. Nature 2000;406:747-752.

-2 Sørlie T, Perou CM, Tibshirani R, Aas T, Geisler S, Johnsen H, Hastie T, Eisen MB, van de Rijn M, Jeffrey SS, Thorsen T, Quist H, Matese JC, Brown PO, Botstein D, Eystein Lønning P, Børresen-Dale AL: Gene expression patterns of breast carcinomas distinguish tumor subclasses with clinical implications. Proc Natl Acad Sci USA 2001;98: 10869-10874.
- 3 Sørlie T, Tibshirani R, Parker J, Hastie T, Marron JS, Nobel A, Deng S, Johnsen H, Pesich R, Geisler S, Demeter J, Perou CM, Lønning PE, Brown PO, Børresen-Dale AL, Botstein D: Repeated observation of breast tumor subtypes in independent gene expression data sets. Proc Natl Acad Sci USA 2003; 100:8418-8423.

4 Sotiriou C, Neo SY, McShane LM, Korn EL, Long PM, Jazaeri A, Martiat P, Fox SB, Harris AL, Liu ET: Breast cancer classification and prognosis based on gene expression profiles from a population-based study. Proc Natl Acad Sci USA 2003;100:10393-10398.

$\checkmark 5$ Nielsen TO, Hsu FD, Jensen K, Cheang M, Karaca G, Hu Z, Hernandez-Boussard T, Livasy C, Cowan D, Dressler L, Akslen LA, Ragaz J, Gown AM, Gilks CB, van de Rijn M, Perou CM: Immunohistochemical and clinical characterization of the basal-like subtype of invasive breast carcinoma. Clin Cancer Res 2004;10:5367-5374.
6 Rakha EA, Putti TC, Abd El-Rehim DM, Paish C, Green AR, Powe DG, Lee AH, Robertson JF, Ellis IO: Morphological and immunophenotypic analysis of breast carcinomas with basal and myoepithelial differentiation. J Pathol 2006;208:495-506.

7 Tischkowitz M, Brunet JS, Begin LR, Huntsman DG, Cheang MC, Akslen LA, Nielsen TO, Foulkes WD: Use of immunohistochemical markers can refine prognosis in triple negative breast cancer. BMC Cancer 2007;7:134.

8 Livasy CA, Karaca G, Nanda R, Tretiakova MS, Olopade OI, Moore DT, Perou CM: Phenotypic evaluation of the basal-like subtype of invasive breast carcinoma. Mod Pathol 2006;19:264-271 
9 Kim MJ, Ro JY, Ahn SH, Kim HH, Kim SB, Gong G: Clinicopathologic significance of the basal-like subtype of breast cancer: a comparison with hormone receptor and Her2/neu-overexpressing phenotypes. Hum Pathol 2006;37:1217-1226.

-10 Tsuda H, Takarabe T, Hasegawa F, Fukutomi T, Hirohashi S: Large, central acellular zones indicating myoepithelial tumor differentiation in high-grade invasive ductal carcinomas as markers of predisposition to lung and brain metastases. Am J Surg Pathol 2000;24: 197-202.

-11 Kallioniemi OP, Holli K, Visakorpi T, Koivula T, Helin $\mathrm{HH}$, Isola JJ: Association of c-erbB-2 protein over-expression with high rate of cell proliferation, increased risk of visceral metastasis and poor long-term survival in breast cancer. Int J Cancer 1991;49: 650-655.

-12 Paik S, Hazan R, Fisher ER, Sass RE, Fisher B, Redmond C, Schlessinger J, Lippman ME, King CR: Pathologic findings from the $\mathrm{Na}-$ tional Surgical Adjuvant Breast and Bowel Project: prognostic significance of erbB-2 protein overexpression in primary breast cancer. J Clin Oncol 1990;8:103-112.

- 13 Shoshani T, Faerman A, Mett I, Zelin E, Tenne T, Gorodin S, Moshel Y, Elbaz S, Budanov A, Chajut A, Kalinski H, Kamer I, Rozen A, Mor O, Keshet E, Leshkowitz D, Einat P, Skaliter R, Feinstein E: Identification of a novel hypoxia-inducible factor 1-responsive gene, RTP801, involved in apoptosis. Mol Cell Biol 2002;22:2283-2293.

-14 Brugarolas J, Lei K, Hurley RL, Manning BD, Reiling JH, Hafen E, Witters LA, Ellisen LW, Kaelin WG Jr: Regulation of mTOR function in response to hypoxia by REDD1 and the TSC1/TSC2 tumor suppressor complex. Genes Dev 2004;18:2893-2904.

-15 DeYoung MP, Horak P, Sofer A, Sgroi D, Ellisen LW: Hypoxia regulates TSC1/2-mTOR signaling and tumor suppression through REDD1-mediated 14-3-3 shuttling. Genes Dev 2008;22:239-251.
16 Reiling JH, Hafen E: The hypoxia-induced paralogs Scylla and Charybdis inhibit growth by down-regulating S6K activity upstream of TSC in Drosophila. Genes Dev 2004;18:2879-2892.

-17 Sofer A, Lei K, Johannessen CM, Ellisen LW: Regulation of mTOR and cell growth in response to energy stress by REDD1. Mol Cell Biol 2005;25:5834-5845.

18 Schneider A, Younis RH, Gutkind JS: Hypoxia-induced energy stress inhibits the mTOR pathway by activating an AMPK/ REDD1 signaling axis in head and neck squamous cell carcinoma. Neoplasia 2008; 10:1295-1302.

19 Elston CW, Ellis IO: Pathological prognostic factors in breast cancer. 1. The value of histological grade in breast cancer: experience from a large study with long-term follow-up. Histopathology 1991;19:403-410.

20 Cutler SJ, Black MM, Mork T, Harvei S, Freeman C: Further observations on prognostic factors in cancer of the female breast. Cancer 1969;24:653-667.

21 Wolff AC, Hammond ME, Schwartz JN, Hagerty KL, Allred DC, Cote RJ, Dowsett M, Fitzgibbons PL, Hanna WM, Langer A, McShane LM, Paik S, Pegram MD, Perez EA, Press MF, Rhodes A, Sturgeon C, Taube SE, Tubbs R, Vance GH, van de Vijver M, Wheeler TM, Hayes DF: American Society of Clinical Oncology/College of American Pathologists guideline recommendations for human epidermal growth factor receptor 2 testing in breast cancer. J Clin Oncol 2007;25:118-145.

22 Brenton JD, Carey LA, Ahmed AA, Caldas C: Molecular classification and molecular forecasting of breast cancer: ready for clinical application? J Clin Oncol 2005;23:7350-7360.

23 Schnitt SJ, Collins LC: Biopsy interpretation of the breast, ed 1. New York, Lippincott Williams and Wilkins, 2009.
24 Jin HO, An S, Lee HC, Woo SH, Seo SK, Choe TB, Yoo DH, Lee SB, Um HD, Lee SJ, Park MJ, Kim JI, Hong SI, Rhee CH, Park IC: Hypoxic condition- and high cell density-induced expression of Redd 1 is regulated by activation of hypoxia-inducible factor- $1 \alpha$ and Sp1 through the phosphatidylinositol 3-kinase/Akt signaling pathway. Cell Signal 2007;19:1393-1403.

-25 Katiyar S, Liu E, Knutzen CA, Lang ES, Lombardo CR, Sankar S, Toth JI, Petroski MD, Ronai Z, Chiang GG: REDD1, an inhibitor of mTOR signalling, is regulated by the CUL4A-DDB1 ubiquitin ligase. EMBO Rep 2009; 10:866-872.

-26 Horak P, Crawford AR, Vadysirisack DD, Nash ZM, DeYoung MP, Sgroi D, Ellisen LW: Negative feedback control of HIF-1 through REDD1-regulated ROS suppresses tumorigenesis. Proc Natl Acad Sci USA 2010;107: 4675-4680.

27 Bos R, van der Groep P, Greijer AE, Shvarts A, Meijer S, Pinedo HM, Semenza GL, van Diest PJ, van der Wall E: Levels of hypoxiainducible factor- $1 \alpha$ independently predict prognosis in patients with lymph node-negative breast carcinoma. Cancer 2003;97: 1573-1581

28 Schindl M, Schoppmann SF, Samonigg H, Hausmaninger $\mathrm{H}$, Kwasny $\mathrm{W}$, Gnant $\mathrm{M}$, Jakesz R, Kubista E, Birner P, Oberhuber G: Overexpression of hypoxia-inducible factor $1 \alpha$ is associated with an unfavorable prognosis in lymph node-positive breast cancer. Clin Cancer Res 2002;8:1831-1837.

-29 Trastour C, Benizri E, Ettore F, Ramaioli A, Chamorey E, Pouyssegur J, Berra E: HIF- $1 \alpha$ and CA IX staining in invasive breast carcinomas: prognosis and treatment outcome. Int J Cancer 2007;120:1451-1458.

30 Laughner E, Taghavi P, Chiles K, Mahon PC, Semenza GL: HER2 (neu) signaling increases the rate of hypoxia-inducible factor $1 \alpha$ $(H I F-1 \alpha)$ synthesis: novel mechanism for HIF-1-mediated vascular endothelial growth factor expression. Mol Cell Biol 2001;21: 3995-4004. 